\title{
ANALISIS KEMAMPUAN KEUANGAN DAERAH PEMERINTAH KABUPATEN JAYAPURA
}

\author{
La Ode Abdul Wahab ${ }^{1}$ \\ jurnalmkd@gmail.com \\ Siti Rofingatun ${ }^{2}$ \\ sitiro@yahoo.co.id \\ Balthazar Kreuta ${ }^{3}$ \\ kreutabalthazar@gmail.com
}

\begin{abstract}
The purpose of this paper is to analyze and obtain empirical evidence about the financial performance of Jayapura regency government in fiscal year 2010-2014, measured from the level of independence of local, regional dependency rate, the level of fiscal decentralization, the level of effectiveness and efficiency of financial management and fiscal capacity Jayapura regency in fiscal year 2010-2014, measured through share and growth Local Revenue.

The results obtained from this study is that the financial capacity of Jayapura regency, measured from the level of the region's autonomy in fiscal year 2010-2014 included in the criteria are lacking, and the level of dependence of the region in that period qualifies as a very high criteria instructive relationship patterns. The ratio of fiscal decentralization is still lacking, the level of effectiveness of regional revenue in 2010-2014 classified in the category of very effective with a ratio of regional revenue collection efficiency is very efficient. The financial capacity of the district of Jayapura in this case the level of independence and dependence of the area and the level of fiscal decentralization is considered good if the government of Jayapura District has been able to raise the percentage of acceptance of regional revenue to be in the top $40 \%$ of the fund balance, because then the Local Revenue will contribute greater of the total regional expenditure.
\end{abstract}

Keywords: financial capacity of local, regional autonomy, regional dependence, fiscal decentralization, effectiveness, efficiency

\section{PENDAHALUAN}

Pelaksanaan otonomi daerah identik dengan adanya tuntutan Good Governance dalam rangka efektifitas dan efisiensi pembangunan daerah dalam kerangka otonomi memerlukan prasyarat berupa tata cara pemerintahan yang baik dan bersih. Terselenggaranya Good Governance merupakan prasayarat utama untuk mewujudkan aspirasi masyarakat dalam mencapai tujuan dan cita-cita Bangsa dan Negara.

Sejak diberlakukannya Otonomi Daerah UU No. 22 Tahun 1999 berubah menjadi UU No. 32 Tahun 2004, tentang Otonomi Daerah UU No. 25 Tahun 1999 menjadi UU No. 33 Tahun 2004 tentang keuangan daerah serta diberikannya

\footnotetext{
${ }^{1}$ Alumni Mahasiswa Magister Keuangan Daerah Universitas Cenderawasih

2 Staf Dosen Jurusan IImu Akuntansi Fakultas Ekonomi \& Bisnis Universitas Cenderawasih

${ }^{3}$ Staf Dosen Jurusan IImu Ekonomi Fakultas Ekonomi \& Bisnis Universitas Cenderawasih
} 
kekhususan tahun 2001 di Papua, merupakan sebagai tonggak baru pengelolaan keuangan daerah di Indonesia sebagai implementasi desentralisasi fiskal di Kabupaten Jayapura.

Kemampuan pemerintah daerah Kabupaten Jayapura dalam mengelola keuangan dituangkan dalam APBD yang langsung maupun tidak langsung mencerminkan kemampuan pemerintah daerah dalam membiayai pelaksanaan tugas-tugas pemerintahan, pembangunan dan pelayanan sosial masyarakat. Untuk itu evaluasi terhadap pengelolaan keuangan daerah dan pembiayaan keuangan daerah akan sangat menentukan kedudukan suatu pemerintah daerah.

Berdasarkan data APBD Kabupaten Jayapura selama 5 (lima) tahun anggaran, pada posisi pendapatan menunjukkan bahwa Dana Perimbangan masih mendominasi penerimaan daerah dibandingkan dengan PAD. Hal ini mengindikasikan masih tingginya ketergantungan fiscal pemerintah daerah Kabupaten Jayapura terhadap Pemerintah Pusat selama kurun waktu 2010-2014 kendati paket otonomi daerah telah digulirkan.

Pada sisi belanja daerah terus mengalami peningkatan dari tahun ke tahun, hal ini merupakan dampak dari kewenangan otonomi daerah, dimana pemerintah daerah secara aktif dan lebih leluasa melakukan pembiayaan dalam upaya pengembangan segala bentuk aktifitas program-program pembangunan di daerah.

Hal inilah yang membuat penulis merasa tertarik untuk melakukan suatu analisis mengenai kemampuan keuangan Daerah Pemerintah Kabupaten Jayapura. Dimana dengan adanya penelitian ini diharapkan dapat memberikan gambaran tentang sejauh mana Pemerintah Daerah Kabupaten Jayapura mampu membiayai pelaksanaan tugas-tugas pemerintahan, pembangunan dan pelayanan sosial masyarakat di tahun-tahun berikutnya.

Berdasarkan uraian mengenai latar belakang masalah, maka yang menjadi tujuan dari penelitian ini adalah untuk menganalisis dan mendapatkan bukti empiris tentang kemampuan keuangan daerah pemerintah Kabupaten Jayapura pada tahun anggaran 2010-2014, diukur dari tingkat kemandirian daerah, tingkat ketergantungan daerah, tingkat desentralisasi fiskal, tingkat efektivitas dan tingkat efisiensi pendapatan asli daerah.

Bastian (2006:189), APBD merupakan "pengejawantahan rencana kerja Pemda dalam bentuk satuan uang untuk kurun waktu satu tahunan dan berorientasi pada tujuan kesejahteraan publik."

Dalam kaitan itu, Saragih (2003:122), "Anggaran Pendapatan dan Belanja Daerah (APBD) adalah dasar dari pengelolaan keuangan daerah dalam tahun anggaran tertentu, umumnya satu tahun." 
Selanjutnya Mamesah dalam Halim (2007:20), APBD dapat didefenisikan sebagai: Rencana operasional keuangan Pemerintah Daerah, dimana disatu pihak menggambarkan perkiraan pengeluaran setinggi-tingginya guna membiayai kegiatan-kegiatan dan proyek-proyek daerah dalam satu tahun anggaran tertentu, dan pihak lain menggambarkan perkiraan penerimaan dan sumber-sumber penerimaan daerah guna menutupi pengeluaran-pengeluaran yang dimaksud.

Dalam Peraturan Menteri Dalam Negeri nomor 13 tahun 2006 tentang pedoman pengelolaan keuangan daerah. Adapun bentuk dan susunan APBD yang didasarkan pada Permendagri 13/ 2006 pasal 22 ayat (1) terdiri atas 3 bagian, yaitu:"pendapatan daerah, belanja daerah, dan pembiayaan daerah."

Menurut Undang-Undang No. 33 Tahun 2004 pasal 6, "Sumber-sumber Pendapatan Asli Daerah terdiri dari:a. Pajak Daerah, b. Retribusi daerah. c. Hasil pengelolaan kekayaan daerah yang dipisahkan, d. Lain-lain Pendapatan Asli Daerah (PAD) yang sah".

Menurut Mardiasmo (2002:132), "Pendapatan Asli Daerah adalah penerimaan daerah dari sektor pajak daerah, retribusi daerah, hasil perusahaan milik daerah, hasil pengelolaan kekayaan daerah yang dipisahkan, dan lain-lain Pendapatan Asli Daerah yang sah".

\section{METODE PENELITIAN}

Analisis kinerja keuangan diukur melalui penghitungan rasio-rasio keuangan yang merupakan alat ukur kemampuan keuangan daerah. Rumus yang digunakan dalam mengukur kemampuan keuangan Pemerintah Kabupaten atau Kota atau Provinsi menurut Halim (2001:127) adalah:

Rasio Kemandirian Keuangan Daerah, Tingkat Kemandirian Keuangan daerah adalah ukuran yang menunjukkan kemampuan keuangan pemerintah daerah dalam membiayai sendiri kegiatan pemerintahan, pembangunan, dan pelayanan kepada masyarakat, yang diukur dengan rasio Pendapatan Asli Daerah (PAD) terhadap jumlah bantuan pemerintah pusat dan pinjaman. Berikut formula untuk mengukur tingkat Kemandirian Keuangan Daerah :

$$
\text { Rasio Kemandirian }=\frac{\text { Pendapatan Asli Daerah }}{\text { Dana Perimbangan }}
$$

Kriteria untuk menetapkan kemandirian keuangan daerah dapat dikategorikan seperti Tabel berikut ini: 
Tabel 1.1 Kriteria Penilaian Kemandirian Keuangan Daerah

\begin{tabular}{|c|c|}
\hline Prosentase PAD terhadap Dana & Kemandirian \\
Perimbangan & Keuangan Daerah \\
\hline $0,00-10,00$ & Sangat Kurang \\
$10,01-20,00$ & Kurang \\
$20,01-30,00$ & Sedang \\
$30,01-40,00$ & Cukup \\
$40,01-50,00$ & Baik \\
$>50,00$ & Sangat Baik \\
\hline
\end{tabular}

Sumber: Tim Litbang Depdagri - Fisipol UGM , 1991

Rasio Ketergantungan Keuangan Daerah, Rasio tingkat ketergantungan keuangan daerah adalah rasio yang dihitung dengan cara membandingkan jumlah pendapatan transfer yang diterima oleh penerimaan daerah dengan total penerimaan daerah. Semakin tinggi rasio ini maka semakin besar tingkat ketergantungan pemerintah daerah terhadap penerimaan pusat dan/atau pemerintah propinsi. Rasio ini dirumuskan sebagai berikut (Mahmudi, 2010 : 142):

$$
\text { Rasio Ketergantungan }=\frac{\text { Pendapatan Asli Daerah }}{\text { Total Penerimaan APBD Tanpa Subsidi }}
$$

Kriteria untuk menetapkan ketergantungan keuangan daerah dapat dikategorikan seperti Tabel berikut ini:

Tabel 1.2 Kriteria Penilaian Ketergantungan Keuangan Daerah

\begin{tabular}{|c|c|}
\hline $\begin{array}{c}\text { Prosentase PAD terhadap Total } \\
\text { Penerimaan Non Subsidi }\end{array}$ & $\begin{array}{c}\text { Ketergantungan } \\
\text { Keuangan Daerah }\end{array}$ \\
\hline $0,00-10,00$ & Sangat Rendah \\
$10,01-20,00$ & Rendah \\
$20,01-30,00$ & Sedang \\
$30,01-40,00$ & Cukup \\
$40,01-50,00$ & Tinggi \\
$>50,00$ & Sangat Tinggi \\
\hline
\end{tabular}

Sumber: Tim Litbang Depdagri - Fisipol UGM , 1991

Rasio Desentralisasi Fiskal, Tingkat Desentralisasi Fiskal adalah ukuran untuk menunjukkan tingkat kewenangan dan tanggung jawab yang diberikan pemerintah pusat kepada pemerintah daerah untuk melaksanakan pembangunan. Tingkat desentralisasi fiskal dalam penelitian ini diukur dengan menggunakan rasio PAD terhadap total penerimaan daerah. Berikut formula untuk mengukur tingkat Desentralisasi Fiskal :

$$
\text { Rasio Desentralisasi Fiskal }=\frac{\text { Pendapatan Asli Daerah }}{\text { Total Penerimaan Daerah }}
$$

Adapun kriteria untuk menetapkan rasio desentralisasi fiskal dapat dikategorikan seperti tabel berikut : 
Tabel 1.3 Kriteria Penilaian Rasio Desentralisasi Fiskal

\begin{tabular}{|c|c|}
\hline $\begin{array}{c}\text { Prosentase PAD terhadap Total } \\
\text { Penerimaan Daerah }\end{array}$ & Desentralisasi Fiskal \\
\hline $0,00-10,00$ & Sangat Kurang \\
$10,01-20,00$ & Kurang \\
$20,01-30,00$ & Sedang \\
$30,01-40,00$ & Cukup \\
$40,01-50,00$ & Baik \\
$>50,00$ & Sangat Baik \\
\hline
\end{tabular}

Sumber: Tim Litbang Depdagri - Fisipol UGM, 1991

Rasio Efektifitas PAD, Rasio efektifitas menggambarkan kemampuan pemerintah daerah dalam merealisasikan pendapatan asli daerah yang direncanakan dibandingkan dengan target yang ditetapkan berdasarkan potensi riil daerah.

$$
\text { Rasio Efektifitas }=\frac{\text { Realisasi PAD }}{\text { Target PAD }}
$$

Adapun kriteria untuk menetapkan rasio efektifitas dapat dikategorikan seperti tabel berikut:

Tabel 1.4 Kriteria Penilaian Efektifitas Pendapatan Asli Daerah

\begin{tabular}{|c|c|}
\hline $\begin{array}{c}\text { Prosentase PAD terhadap Total } \\
\text { Penerimaan Daerah }\end{array}$ & Tingkat Efektivitas \\
\hline Di atas $100 \%$ & Sangat Efektif \\
$90 \%-100 \%$ & Efektif \\
$80 \%-90 \%$ & Cukup Efektif \\
$60 \%-80 \%$ & Kurang Efektif \\
Kurang dari $60 \%$ & Tidak Efektif \\
\hline
\end{tabular}
Sumber: Depdagri, Kepmendagri No. 690.900.327, 1996

Pemerintah daerah dalam melakukan pemungutan pendapatan dikategorikan efektif apabila nilai prosentasinya besar. Semakin besar rasio ektifitas berarti kinerja pemerintahan daerah semakin baik.

Rasio Efisiensi PAD, Rasio efisiensi adalah rasio yang menggambarkan perbandingan antara besarnya biaya yang dikeluarkan untuk memperoleh pendapatan dengan realisais pendapatan yang diterima. Pemerintah daerah dalam melakukan pemungutan pendapatan dikategorikan efisien apabila yang dicapai kurang dari 1 (satu) atau dibawah 100 persen. Semakin kecil rasio efisiensi berarti kinerja pemerintahan daerah semakin baik.

$$
\text { Rasio Efisiensi }=\frac{\text { Biaya yang dikeluarkan untuk memungut PAD }}{\text { Realisasi Penerimaan PAD }}
$$


Tabel 1.5 Kriteria Penilaian Efisien

\begin{tabular}{|c|c|}
\hline $\begin{array}{c}\text { Prosentase PAD terhadap Total } \\
\text { Penerimaan Daerah }\end{array}$ & Tingkat Efisiensi \\
\hline $100 \%$ ke atas & Tidak Efisien \\
$90 \%-100 \%$ & Kurang Efisien \\
$80 \%-90 \%$ & Cukup Efisien \\
$60 \%-80 \%$ & Efisien \\
Dibawah $60 \%$ & Sangat Efisien \\
\hline
\end{tabular}

Sumber: Depdagri, Kepmendagri No. 690.900.327, 1996

\section{HASIL DAN PEMBAHASAN}

Rasio Kemandirian Keuangan Daerah Kabupaten Jayapura, Tingkat Kemandirian Keuangan daerah adalah ukuran yang menunjukkan kemampuan keuangan pemerintah daerah dalam membiayai sendiri kegiatan pemerintahan, pembangunan, dan pelayanan kepada masyarakat, yang diukur dengan rasio Pendapatan Asli Daerah (PAD) terhadap jumlah bantuan pemerintah pusat dan pinjaman.

Berdasarkan hasil penelitian penulis dengan menggunakan data-data sekunder yang diperoleh, maka tingkat kemandirian keuangan daerah Kabupaten Jayapura dapat dilihat pada tabel berikut ini:

Tabel 1.6 Rasio Kemandirian Keuangan Daerah Kabupaten Jayapura Tahun 2010-2014

\begin{tabular}{|c|c|c|c|c|c|}
\hline Tahun & $\begin{array}{l}\text { Pendapatan Asli } \\
\text { Daerah (PAD) }\end{array}$ & $\begin{array}{c}\text { Dana } \\
\text { Perimbangan }\end{array}$ & $\begin{array}{c}\text { Rasio } \\
\text { Kemandirian }\end{array}$ & Keterangan & $\begin{array}{c}\text { Pola } \\
\text { hungan }\end{array}$ \\
\hline 2010 & 28.812.145.760 & 501.433 .089 .663 & 5,75 & Sangat kurang & Instruktif \\
\hline 2011 & 24.319 .641 .889 & 517.659 .850 .489 & 4,70 & Sangat Kurang & Instruktif \\
\hline 2012 & 32.544 .334 .958 & 598.279 .667 .656 & 5,44 & Sangat Kurang & Instruktif \\
\hline 2013 & 47.003 .680 .309 & 636.419.891.977 & 7,39 & Sangat Kurang & Instruktif \\
\hline 2014 & 81.007 .745 .806 & 708.726 .243 .361 & 11,43 & Kurang & Instruktif \\
\hline \multicolumn{3}{|c|}{ Rata-R } & 6,94 & & \\
\hline
\end{tabular}

Sumber: Data Primer Diolah, 2016

Tabel 1.6 di atas, rata-rata tingkat kemandirian keuangan daerah Kabupaten Jayapura selama periode tahun anggaran 2010-2014 adalah sebesar $6,94 \%$, sehingga diklasifikasikan menurut kriteria penilaian kemandirian keuangan daerah adalah Kabupaten Jayapura dengan tingkat kemandirian keuangan daerah sangat kurang. Hal ini menunjukkan bahwa Kabupaten Jayapura selama periode tahun anggaran 2010-2014 memiliki ketergantungan tinggi terhadap bantuan pemerintah pusat melalui dana perimbangan, dan jika dihubungkan dengan pola hubungan antara pemerintah pusat dan daerah, maka Kabupaten 
Jayapura masuk dalam kategori pola hubungan instruktif, dimana peranan pemerintah pusat lebih dominan daripada kemandirian pemerintah daerah.

Rasio Kemadirian yang masih rendah menunjukan bahwa pada sumber penerimaan daerah masih kurang maksimal. Hal ini dikarenakan masih relatif kurangnya PAD yang dapat digali oleh pemerintah daerah, sedangkan untuk pajak yang cukup besar masih dikelola oleh pemerintah pusat, yang dalam pemungutan berdasarkan undang-undang/persyaratan pemerintah dan daerah hanya menjalankan serta menerima bagian dalam bentuk dana perimbangan yang terdiri dari bagi hasilpajak/bukan pajak, DAU, DAK dan bantuan propinsi.

Inisiatif, kreatifitas dan kemauan daerah sangat diperlukan dalam meningkatkan PAD. Pemerintah daerah harus mencari jalan yang dapat memungkinkan mengatasi kekurangan pembiayaannya, hal ini memerlukan kreatifitas dari aparat pelaksana keuangan daerah untuk mencari sumber-sumber pembiayaan dalam program peningkatan PAD.

Rasio Ketergantungan Keuangan Daerah. Tingkat Ketergantungan Daerah adalah ukuran tingkat kemampuan daerah dalam membiayai aktifitas pembangunan daerah melalui optimalisasi PAD, yang diukur dengan rasio antara PAD dengan total penerimaan Anggaran Pendapatan dan Belanja Daerah (APBD) tanpa subsidi (Dana Perimbangan).

Dari hasil analisis yang dilakukan penulis diperoleh data ketergantungan keuangan daerah Kabupaten Jayapura tahun 2010-2014 sebagai berikut:

Tabel 1.7 Rasio Ketergantungan Keuangan Daerah Kabupaten Jayapura Tahun 2010-2014

\begin{tabular}{|r|r|r|r|r|r|}
\hline Tahun & Dana Perimbangan & $\begin{array}{c}\text { Total Penerimaan } \\
\text { Daerah }\end{array}$ & $\begin{array}{c}\text { Rasio } \\
\text { Ketergantungan }\end{array}$ & Keterangan & $\begin{array}{c}\text { Pola } \\
\text { hubungan }\end{array}$ \\
\cline { 1 - 5 } 2010 & $501,433,089,663$ & $669,100,670,982$ & 74.94 & Sangat Tinggi & Instruktif \\
\hline 2011 & $517,659,850,489$ & $709,148,045,861$ & 73 & Sangat Tinggi & Instruktif \\
\hline 2012 & $598,279,667,656$ & $751,825,620,630$ & 79.58 & Sangat Tinggi & Instruktif \\
\hline 2013 & $636,419,891,977$ & $868,437,011,822$ & 73.28 & Sangat Tinggi & Instruktif \\
\hline 2014 & $708,726,243,361$ & $1,004,538,507,482$ & 70.55 & Sangat Tinggi & Instruktif \\
\hline Rata-Rata & & & 74.27 & & \\
\hline
\end{tabular}

\section{Sumber: Data Primer Diolah, 2016}

Tabel $1.7 \mathrm{di}$ atas, rata-rata tingkat ketergantungan keuangan daerah Kabupaten Jayapura selama periode tahun anggaran 2010-2014 adalah sebesar $74,27 \%$, sehingga diklasifikasikan menurut kriteria penilaian ketergantungan keuangan daerah adalah sangat tinggi. Terlebih lagi pada tahun 2012, rasio 
ketergantungan keuangan daerah Kabupaten Jayapura mencapai 79,58\%, hal ini dikarenakan pada tahun tersebut penerimaan dana perimbangan mengalami kenaikan sebesar Rp. 80.619.817.167 atau sebesar 13\% dari tahun sebelumnya. Hal ini juga menggambarkan bahwa pada tahun tersebut ketergantungan pemerintah Kabupaten Jayapura terhadap bantuan pemerintah pusat dalam hal ini dana perimbangan, sangat tinggi.

Rasio Desentralisasi Fiskal. Tingkat Desentralisasi Fiskal adalah ukuran untuk menunjukkan tingkat kewenangan dan tanggung jawab yang diberikan pemerintah pusat kepada pemerintah daerah untuk melaksanakan pembangunan. Tingkat desentralisasi fiskal dalam penelitian ini diukur dengan menggunakan rasio PAD terhadap total penerimaan daerah.

Rasio Desentralisasi Fiskal juga merupakan rasio untuk mengukur tingkat kemampuan pemerintah daerah dalam rangka meningkatkan Pendapatan Asli Daerah guna membiayai pembangunan. Derajat Desentralisasi Fiskal, khususnya komponen Pendapatan Asli Daerah (PAD) dibandingkan dengan Total Pendapatan Daerah (TPD) di kali 100\% (seratus persen).

Secara umum, semakin tinggi Skala Interval Derajat Desentralisasi Fiskal berarti semakin tinggi tingkat Kemampuan Keuangan Daerah untuk membiayai pembangunan daerahnya. Dan sebaliknya, semakin rendah Skala Interval Derajat Desentralisasi Fiskal berarti semakin rendah Kemampuan Keuangan Daerah untuk membiayai pembangunan daerahnya.

Berdasarkan hasil penghitungan yang dilakukan penulis, diperoleh besarnya rasio desentralisasi fiscal Kabupaten Jayapura tahun 2010-2014 sebagai berikut:

Tabel 1.8 Rasio Desentralisasi Fiskal Kabupaten Jayapura Tahun 2010-2014

\begin{tabular}{|r|r|r|r|l|}
\hline \multirow{2}{*}{ Tahun } & \multicolumn{2}{|c|}{ Pendapatan Asli Daerah } & \multirow{2}{*}{ Kriteria } & \multirow{2}{*}{ Hubungan } \\
\cline { 2 - 3 } & Total Penerimaan Daerah & Rasio Desentralisasi Fiskal & & \\
\hline 2010 & $28,812,145,760$ & $669,100,670,982$ & 4.31 & Sangat Kurang \\
\hline 2011 & $24,319,641,889$ & $709,148,045,861$ & 3.43 & Sangat Kurang \\
\hline 2012 & $32,544,334,958$ & $751,825,620,630$ & 4.33 & Sangat Kurang \\
\hline 2013 & $47,003,680,309$ & $868,437,011,822$ & 5.41 & Sangat Kurang \\
\hline 2014 & $81,007,745,806$ & $1,004,538,507,482$ & 8.06 & Sangat Kurang \\
\hline \multicolumn{2}{|r|}{ Rata-Rata } & & 5.11 & \\
\hline
\end{tabular}

Sumber: Data Primer Diolah, 2016

Dari hasil perhitungan Rasio Desentralisasi Fiskal tersebut dapat dilihat bahwa tingkat kemampuan pemerintah daerah Kabupaten Jayapura dalam 
melaksanakan otonomi daerah selama tahun 2010-2014 dalam hal peningkatan Pendapatan Asli Daerah masih sangat kurang karena hanya memberikan kontribusi rata-rata sebesar $5,11 \%$ dari total pendapatan daerah.

Rasio Efektifitas Pendapatan Asli Daerah. Rasio efektifitas menggambarkan kemampuan pemerintah daerah dalam merealisasikan pendapatan asli daerah yang direncanakan dibandingkan dengan target yang ditetapkan berdasrkan potensi riil daerah. Kemampuan daerah dalam menjalankan tugas dikategorikan efektif apabila rasio yang dicapai minimal sebesar satu atau 100 persen. Namun demikian, semakin tinggi rasio efektivitas, maka kemampuan daerah pun semakin baik.

Adapun hasil perhitungan tingkat efektivitas pendapatan asli daerah, dapat dilihat pada table berikut ini:

Tabel 1.9 Tingkat Efektivitas Pendapatan Asli Daerah Kabupaten Jayapura Tahun 2010-2014

\begin{tabular}{|c|c|c|c|c|}
\hline Tahun & $\begin{array}{c}\text { Realisasi Pendapatan } \\
\text { Asli Daerah } \\
\text { (PAD) }\end{array}$ & $\begin{array}{c}\text { Target } \\
\text { Pendapatan Asli } \\
\text { Daerah } \\
\text { (PAD) }\end{array}$ & $\begin{array}{c}\text { Rasio } \\
\text { Efektivitas }\end{array}$ & Kritera \\
\hline 2010 & $28,812,145,760$ & $23,263,943,124$ & 123.85 & Sangat Efektif \\
\hline 2011 & $24,319,641,889$ & $24,961,254,000$ & 97.43 & Efektif \\
\hline 2012 & $32,544,334,958$ & $32,113,751,921$ & 101.34 & Sangat Efektif \\
\hline 2013 & $47,003,680,309$ & $34,516,471,560$ & 136.18 & Sangat Efektif \\
\hline 2014 & $81,007,745,806$ & $66,596,408,557$ & 121.64 & Sangat Efektif \\
\hline & Rata-Rata & 116.09 & \\
\hline
\end{tabular}

Sumber: Data Primer Diolah, 2016

Berdasarkan hasil penelitian efektivitas PAD di Kabupaten Jayapura tahun 2010-2014 dapat dijelaskan bahwa efektivitas PAD di Kabupaten Jayapura pada tahun 2010 sampai dengan 2014 tergolong dalam katagori sangat efektif dengan rata-rata selama lima tahun terakhir sebesar 116,09 persen.

Rasio Efisiensi, Kinerja keuangan pemerintah daerah dalam melakukan pemungutan pendapatan dikategorikan efisien apabila yang dicapai kurang dari 1 (satu) atau dibawah 100 persen. Semakin kecil rasio efisiensi berarti kinerja pemerintahan daerah semakin baik.

Berdasarkan hasil perhitungan tingkat efisiensi pemungutan pendapatan asli daerah Kabupaten Jayapura pada tahun 2010 sampai dengan 2014, diperoleh data-data sebagai berikut: 
Tabel 1.10 Tingkat Efisiensi Pemungutan Pendapatan Asli Daerah Kabupaten Jayapura Tahun 2010-2014

\begin{tabular}{|c|c|c|c|c|}
\hline Tahun & $\begin{array}{c}\text { Realisasi } \\
\text { Pendapatan Asli Daerah } \\
\text { (PAD) }\end{array}$ & $\begin{array}{l}\text { Biaya Pemungutan } \\
\text { Pendapatan Asli } \\
\text { Daerah } \\
\text { (PAD) }\end{array}$ & $\begin{array}{c}\text { Rasio } \\
\text { Efisiensi }\end{array}$ & Kriteria \\
\hline 2010 & 28.812 .145 .760 & 1.163.197.156 & 4,04 & Tidak Efekti \\
\hline 2011 & 24.319 .641 .889 & 1.248 .062 .700 & 5,13 & Tidak Efekti \\
\hline 2012 & 32.544 .334 .958 & 1.605 .687 .596 & 4,93 & Tidak Efekti \\
\hline 2013 & 47.003 .680 .309 & 1.725 .823 .578 & 3,67 & Tidak Efekti \\
\hline 2014 & 81.007 .745 .806 & 3.329.820.428 & 4,11 & Tidak Efekti \\
\hline
\end{tabular}

Sumber: Data Primer Diolah, 2016

Dari hasil perhitungan Rasio efisiensi tersebut dapat dilihat bahwa tingkat efisiensi pemungutan pendapatan asli daerah pemerintah daerah Kabupaten Jayapura selama tahun 2010-2014 sudah sangat efisien, hal ini dikarenakan ratarata rasio efisiensi pemungutan Pendapatan Asli Daerah Kabupaten Jayapura selama lima tahun terakhir adalah sebesar 4,38 persen, dimana semakin kecil rasio efisiensi berarti kinerja pemerintahan daerah semakin baik dalam pemungutan pendapatan asli daerah.

\section{KESIMPULAN DAN SARAN}

\section{Kesimpulan}

Berdasarkan hasil analisis penulis mengenai kinerja keuangan daerah Kabupaten Jayapura periode 2010 sampai dengan 2014, maka penulis menarik kesimpulan bahwa kemampuan keuangan Daerah Kabupaten Jayapura pada Tahun Anggaran 2010-2014 diukur berdasarkan rasio Ketergantungan Keuangan Daerah, masuk dalam criteria daerah dengan tingkat ketergantungan yang masih Sangat Tinggi. Hal inilah yang menyebabkan tingkat Kemandirian Daerah Sangat Kurang, sehingga dengan sendiriya tingkat Desentralisasi Fiskal juga masuk dalam kriteria sangat kurang. Namun, efektifitas penerimaan PAD Kabupaten Jayapura sudah Sangat Efektif, dan Efisiensi pengelolaan PAD juga sudah menunjukkan hasil yang Sangat Efisien, akan tetapi harus tetap ditingkatkan sehingga dapat mengurangi ketergantungan keuangan daerah Kabupaten Jayapura terhadap pemerintah pusat.

Kemampuan keuangan daerah Kabupaten Jayapura dalam hal ini tingkat kemandirian dan ketergantungan daerah serta tingkat desentralisasi fiscal dinilai baik jika pemerintah Kabupaten Jayapura sudah bisa menaikkan prosentase penerimaan Pendapatan Asli Daerah menjadi di atas 40\% terhadap dana 
perimbangan, karena dengan demikian Pendapatan Asli Daerah akan memberikan kontribusi yang lebih besar terhadap total Belanja Daerah.

\section{Saran}

Pemeritah Kabupaten Jayapura harus mampu menggali potensi-potensi sumber pendapatan asli daerah yang baru dengan memanfaat sumber dayasumber daya yang telah ada, seperti pengelolaan Danau Sentani menjadi tempat wisata dan daerah transmigrasi Kertosai menjadi daerah Agrowisata, sehingga dapat memberikan kontribusi terhadap penerimaan Pendapatan Asli Daerah.

Pemerintah Kabupaten Jayapura harus meningkatkan sosialisasi manfaat pajak dan retribusi kepada masyarakat, sehingga mampu meningkatkan kesadaran masyarakat untuk membayar pajak dan retribusi.

Kurangnya pembekalan kepada personil penagihan yang langsung turun ke lapangan untuk melakukan penagihan langsung, juga menyebabkan masih kurang maksimalnya penerimaan pajak dan retribusi daerah, sehingga perlu adanya pelatihan yang lebih rutin kepada personil penagihan yang langsung turun ke lapangan.

\section{DAFTAR PUSTAKA}

Azhar, Mhd Karya Satya, 2008. "Analisis Kinerja Keuangan Pemerintahan Daerah Kabupaten/Kota Sebelum dan Setelah Otonomi Daerah", Tesis, Departemen Akuntansi Sekolah Pasca Sarjana Fakultas Ekonomi, Universitas Sumatera Utara, Medan.

Badan Litbang Depdagri RI dan FISIPOL - UGM, 1991, Pengukuran Kemampuan Keuangan Daerah

Badan Pusat Statistik Kabupaten Jayapura dan Badan Perencanaan Pembangunan Daerah Kota Jayapura 2013

Bastian, Indra, 2006. Akuntansi Sektor Publik Suatu Pengantar, Salemba Empat, Jakarta.

Bastian,Indra, 2004. Manual Akuntansi Keuangan Pemerintahan Daerah, BPFE , Yogyakarta.

Erfa, Azhir, 2008. "Analisis Kinerja Keuangan Pemerintahan Daerah Setelah Otonomi Khusus (Studi Kasus Pada Pemerintahan Daerah Kabupaten Aceh Utara)", Skripsi, Departemen Akuntansi Fakultas Ekonomi Universitas Sumatera Utara

Halim, Abdul dan Jamal Abdul Nasir, 2006. "Kajian tentang Keuangan Daerah Pemerintah Kota Malang", Jurnal Manajemen Usahawan, Nomor 06 Th XXXV Juni 2006, Lembaga Management FE-UI, Jakarta, hal 42.

Halim, Abdul, 2001, Manajemen Keuangan Daerah, Yogyakarta: UPP-AMP YKPN 
Halim, Abdul, 2002, Akuntansi Sektor Publik, Jakarta: Salemba Empat.

Halim, Abdul, 2004. Akuntansi Keuangan Daerah, Edisi Revisi, Penerbit Salemba Empat.

Halim, Abdul, 2007. Akuntansi Sektor Publik Akuntansi Keuangan Daerah, Edisi Ketiga, Penerbit Salemba Empat.

Haryati, Sri, 2006. "Perbandingan Kinerja Keuangan Daerah Sebelum dan Sesudah Kebijakan Otonomi Daerah Kabupaten Sleman Tahun 1998-2000 dan 2000-2001", Skripsi, Departemen Akuntansi Fakultas Ekonomi, Universitas Islam Indonesia, Yogyakarta.

Husein Umar, 2003, Metodologi Penelitian Untuk Skripsi dan Tesis Bisnis, Jakarta. : PT. Gramedia Pustaka

Mahmudi. 2010. Analisis Laporan Keııngan Pemerintah Daerah Edisi Kedua. Yogyakarta: Sekolah Tinggi IIr najemen YKPN.

Mardiasmo, 2002. Otonomi dan Manajemen Keuangan Daerah, Penerbit Andi, Yogyakarta.

Republik Indonesia 2004. Undang-undang Nomor 32 Tahun 2004 tentang Pemerintahan Daerah.

Republik Indonesia 2004. Undang-undang Nomor 33 Tahun 2004 tentang Perimbangan antara Keuangan Pemerintah Pusat dan Pemerintah Daerah.

Republik Indonesia 2006. Peraturan Menteri Dalam Negeri Nomor 13 Tahun 2006 tentang Pedoman Pengelolaan Keuangan Daerah.

Republik Indonesia 2006. Peraturan Pemerintah Nomor 8 Tahun 2006 tentang Pelaporan Keuangan dan Kinerja Instansi Pemerintah.

Republik Indonesia, 2002. Keputusan Menteri Dalam Negeri Nomor 29 Tahun 2002 tentang Pedoman Pengurusan, Pertanggungjawaban dan Pengawasan Keuangan Daerah Serta Tata Cara Penyusunan Anggaran Pendapatan dan Belanja Daerah, Pelaksanaan Tata Usaha Keuangan Daerah dan Penyusunan Perhitungan Anggaran Pendapatan dan Belanja Daerah.

Saragih, Juli Panglima, 2003. Desentralisasi Fiskal dan Keuangan Daerah dalam Otonomi, Penerbit Ghalia Indonesia, Jakarta.

Sedarmayanti, 2003. Good Governanace (Kepemerintahan Yang Baik) Dalam Rangka Otonomi Daerah : Upaya Membangun Organisasi Efektif dan Efisisen Melalui Restrukturisasi dan Pemberdayaan. Mandar Maju, Bandung.

Tangkilisan, Hesel Nogi S, 2003. Kebijakan Publik Yang Membumi (Konsep dan Strategi), Cetakan Pertama, Penerbit Yayasan Pembaharuan Administrasi Publik

Wajong J., Administrasi Keuangan Daerah, Cetakan ke III, Jakarta, Penerbit Balai Buku Ichtiar, 1998. 